\section{Acta 3iologica Gibirica}

Journal of Biology

Founded in 2015
Altai State University

www.asu.ru

ISSN 2412-1908

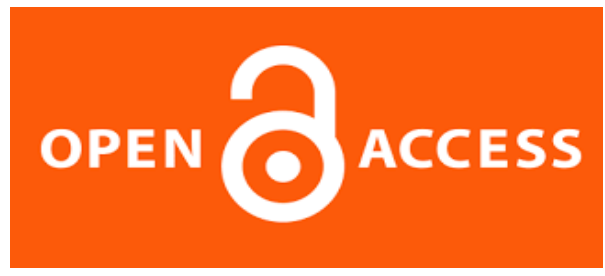

Acta Biologica Sibirica, 2017, 3(3), 32-38

UDC 551.312.2

\title{
The diversity of microorganisms inhabiting the sludge tanks of Baikalsk pulp and paper plant (BPPP)
}

\author{
V.V. Malnik, A.N. Suturin \\ Limnological Institute of the Siberian Branch \\ of the Russian Academy of Sciences, Irkutsk, Russia \\ malnik80@mail.ru; san@lin.irk.ru
}

\begin{abstract}
The wastes from the Baikalsk pulp and paper plant, including the by-products of the plant's bleaching unit are stored in the special disposal reservoirs in the form of a sludge-lignin, which consists of lignin, polyacrylamide and flocculants. Here, we report on microbiological composition of sludge-lignin: we detected fungi hyphae, actinomycete hyphae, long and short rods as well as coccal forms of bacteria. Interestingly, despite the diversity of bacterial, cyanobacterial and fungal communities no noticeable destruction of lignin was observed. We recommend to use specific chemical compounds and microbiological agents for destruction of sludge-lignin.
\end{abstract}

Key words: slime-lignin; overmud water; microbiological destruction; Baikalsk PPP

\section{Разнообразие микроорганизмов, обитающих в шламонакопителях Байкальского целлюлозно- бумажного комбината}

\author{
В.В. Мальник, А.Н. Сутурин \\ Лимнологический институт Сибирского отделения \\ Российской Академии наук, Иркутск, Россия \\ malnik80@mail.ru; san@lin.irk.ru
}

\begin{abstract}
Отходы Байкальского ЦБК после двухступенчатой биологической и химической очистки складировались в картах на полигоне промышленных отходов в виде шлам-лигнина, состоящего из лигнина, полиакриламида, флокулянтов и отходов отбельного цеха. Согласно нашим данным, в этих картах в пробах надшламовой воды присутствовали гифы грибов, актиномицетов, длинные и короткие палочки, а также кокковые формы бактерий. Несмотря на разнообразие микроорганизмов, цианобактериального и грибного сообществ интенсивной деструкции лигнина не наблюдалось. Для преобразования шлам-лигнина требуются специальные рекультивационные работы, в том числе, с применением микробиологических лигнин-деструкторов.

Ключевые слова: шлам-лигнин; надшламовая вода; микробиологическая деструкция; Байкальский ЦБК
\end{abstract}


Malnik, V.V., Suturin, A.N. (2017 The diversity of microorganisms .... Acta Biologica Sibirica, 2017, 3(3), 32-38

\section{Введение}

Лигнин - это главный компонент растительных тканей, и он является самым широко распространенным ароматическим веществом в биосфере. Химически, лигнин - это неоднородный, оптически неактивный полимер, состоящий из фенилпропаноидных мономеров, связанных различными типами ковалентных связей (например, арил-эфирной, арил-арильной и углерод-углеродной связями) (Brunow, 2001). Как неотъемлемая составляющая клеточной стенки лигнин обеспечивает растения прочностью и устойчивостью (Argyropoulos, Menachem, 1997). Более того, лигнин принимает участие в водном транспорте у растений и формирует барьер против микробного воздействия, защищая легко усвояемые полисахариды (Monties, Fukushima, 2001). Тем не менее, одновременно с заселением суши сосудистыми растениями в палеозойскую эру, около 400 млн л.н. эволюционировали и разрушающие лигнин микроорганизмы (Taylor, Osborne, 1996). Микробное разложение лигнина (Martinez et al., 2005; Kersten, Cullen, 2007; Jing et al., 2009) представляет основной шаг для завершения цикла углерода, поскольку удаление лигнинового барьера сделало бы возможным последующее использование растительных углеводов другими микроорганизмами (Ruiz-Duenas, Martinez, 2009).

Деградация лигнина включает многочисленные биохимические реакции, которые могут осуществлять ферменты, продуцируемые микроорганизмами. Сложная химическая структура лигнина требует, чтобы эти ферменты были разнообразны и были способны расщеплять очень широкий ряд химических соединений. Сравнительно недавно, используя простые модельные соединения, было продемонстрировано, что среди различных окислительных энзимов, выработанных лигнин-разрушающими организмами, только группа гемпероксидаз базидиомицетов могла непосредственно атаковать нефенольную лигнинную цепь (Martinez, 2002; Hammel, Cullen, 2008). Известно, что бактерии нескольких родов, таких как Alcaligenes, Arthrobacter, Nocardia, Pseudomonas и Streptomyces легко деградируют одиночные кольцевые ароматические вещества. Гены, вовлеченные в деградацию лигнина, были клонированы и экспрессированы (Jing et al., 2009).

Удаление лигнина является центральным аспектом в промышленных использованиях целлюлозной биомассы, таких как производство биоэтанола и целлюлозо-основанных химических реактивов и материалов, включая бумагу. В растительной клеточной стенке лигнин концентрируется в межклеточной пластинке, причем его самый внешний слой действует как цементирующий агент между волокнами. Производство целлюлозной пульпы по существу состоит в разрушении (химически или механически) межклеточной пластинки таким путем, чтобы древесные волокна разделялись (Sixta, 2006). Лигнин также присутствует во вторичной клеточной стенке, более толстом клеточно-стеночном слое, где он тесно связан с углеводами, мешая их эффективному гидролизу при выработке биоэтанола (Galbe, Zacci, 2007). В упомянутых промышленных применениях биотехнология, основанная на лигнин-разрушающих микробах и их ферментах, может внести вклад в более эффективное и качественное использование возобновимого лигниноцеллюлозного сырья для экологически рациональной выработки материалов, химических реактивов, биотоплива и энергии (Ruiz Duenas, Martinez, 2009).

В целлюлозно-бумажной промышленности (ЦБП) лигнин является главным промышленным отходом. Сточные воды ЦБП из-за значительного количества в их составе лигнина являются опасными для экосистем рек и озер. На Байкальском ЦБК после двухступенчатой биологической и химической очистки шлам-лигнин, состоящий из лигнина, полиакриламида, флокулянтов, отходов отбельного цеха и имеющий влажность 90-95 \%, складировался в картах на полигоне промышленных отходов (рис. 1). Всего на 10 картах полигона накоплено 6,2 млн. м шлам-лигнина. За многие десятилетия хранения в отстойниках не изменилась влажность шлам-лигнина, его химический состав, не наблюдались процессы деструкции. Сульфатсодержащие соединения преобразованы в сероводород. В последние 20 лет на карты «Б-4-Б-7» стали сливать зольную пульпу от угольной ТЭЦ. Зола перекрывает шлам-лигнин 1-1,5 м слоем.

Состав надшламовых вод за годы хранения преобразовался в щелочной с рН до 10 единиц, нижний слой шлам-лигнина остался неизменным (Suturin et al., 2015). Проблема переработки накопившегося лигнина и надшламовой воды до сих пор остается актуальной, поскольку все карты с отходами производства Байкальского ЦБК находятся в нетронутом состоянии.

Настоящее исследование проведено с целью выяснения морфологического разнообразия микроорганизмов, развивающихся в надшламовой воде карт, и определения их возможного участия в деструкции лигнина.

\section{Материалы и методы исследований}

Материалом для исследования послужили образцы шлам-лигнина Солзанской площадки, а также образцы надшламовой воды карт, взятые с поверхности. Месторасположение: пос. Солзан вблизи г. Байкальска (рис. 1). Отбор проб производился 5 октября 2011 г. Образцы лигнина отбирали с помощью обрезанных у основания стерильных 10 мл шприцов и помещали в стерильные 5 мл пластиковые пробирки с винтовой крышкой. Пробы надшламовой воды карт отбирали стерильным шприцом Жанэ объемом 150 мл в стерильные 100 мл или 250 мл флаконы в зависимости от цели исследования. Все пробы помещались в сумку-холодильник и доставлялись в лабораторию. Анализ выполнялся в течение 6 час. с момента отбора проб. До этого момента пробы, доставленные в лабораторию, хранили в холодильнике.

В работе были использованы следующие методы: метод эпифлуоресцентной микроскопии (Hobbie et al., 1977) для подсчета общей численности бактерий (ОЧБ), метод сканирующей электронной микроскопии (Danilatos, 
1986), а также метод окрашивания с помощью акридина оранжевого (Jones, Simon, 1975) для визуализации морфологии микробного сообщества. Также применяли традиционные методы классической микробиологии (Rodina, 1965). Были использованы следующие питательные среды: среда Ваксмана для определения выросших KOE грибов и актиномицетов (Rodina, 1965), среда РПА-10 - для определения сапрофитов (Gorbenko, 1961), жидкая среда Гетчинсона (Kuznetsov, Romanenko, 1963) для определения целлюлозоразлагающих бактерий, крахмальный агар (Rodina, 1965) в качестве подложки для роста целлюлозоразлагающих бактерий, среда для сульфатредуцирующих бактерий (Lengler et al., 2005), соответственно для их определения, среда Эндо для определения бактерий группы кишечной палочки (Endo, 1904), желчный эскулиновый азидный агар (Нimedia production, No. M493) и среда Сланеца и Бартли (Himedia production, No. M 612) для определения энтерококков.

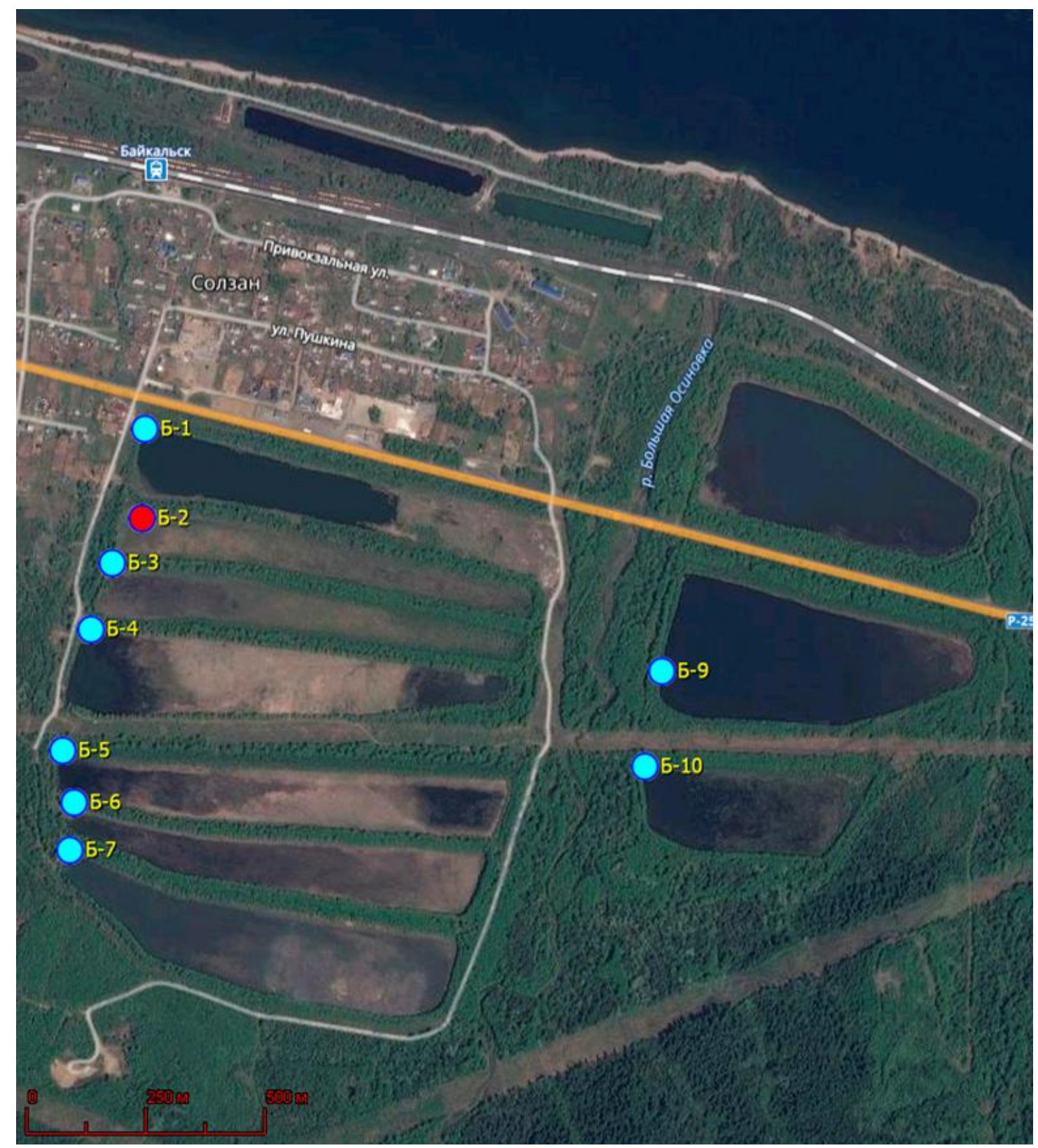

Рис. 1. Космоснимки с мест отбора проб: условные названия карт Солзанской площадки.

Голубым значком обозначены карты, в которых мы отбирали пробы надшламовой воды и лигнина, красным - место, где проводился отбор проб исключительно шлам-лигнина, поскольку надшламовая вода отсутствовала

\section{Результаты и их обсуждение}

Исследования показали, что в надшламовой воде общая численность бактерий (ОчБ) была различной в зависимости от места отбора проб (табл. 1). 
Таблица 1. Общая численность бактерий (ОЧБ) и концентрация гетеротрофных бактерий в надшламовой воде исследованных карт

Названия карт

«Б-1» «Б-3» «Б-4» «Б-5» «Б-6» «Б-7» «Б-9» «Б-10»

ОЧБ,

58

6,4

16,5

43,3

14,6

17,7

6,7

5,6

млн кл./мл

Гетеротрофы,

75

95

320

660

31

98

90

24

тыс. кл./мл

Морфологическое разнообразие микроскопических организмов в данных образцах включало характерные формы клеток для бактерий, грибов, актиномицетов и цианобактерий. Самое большое разнообразие микроорганизмов было обнаружено в пробах воды карты «Б-1», «Б-5» и «Б-7» (рис. 1), что позволяет предположить, что в этих пробах присутствовали спорообразующие и неспорообразующие бактерии, которые составляли значительную численность. В данных пробах отмечено развитие плесневых грибов и актиномицетов с хорошо развитыми спорангиями. Морфологическое разнообразие в пробах воды из карт «Б-9» и «Б-10» было небольшим, то есть преобладала небольшая группа микроорганизмов, составляющая основную биомассу сообщества. В пробе воды «Б-1» доминирующими были плесневые грибы и мелкие формы микроорганизмов. Количество плесневых грибов в пробе «Б-1» было настолько большим, что затрудняло подсчет микроорганизмов (рис. 2-4).
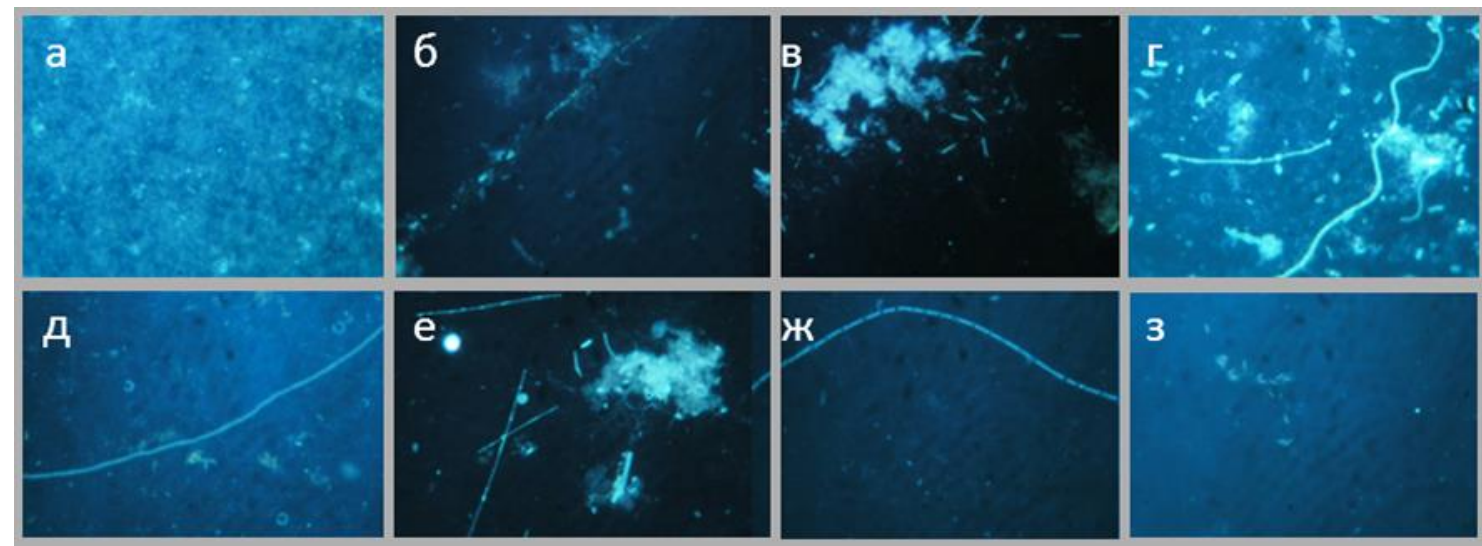

Рис. 2. Морфологическая характеристика микробного сообщества в пробах надшламовой воды, окраска по ДАФИ: а - карта «Б-1»; б - карта «Б-3»; в - карта «Б-4»; г - карта «Б-5»; д - карта «Б-6»; е - карта «Б-7»; ж - карта «Б-9»; з - карта «Б-10»
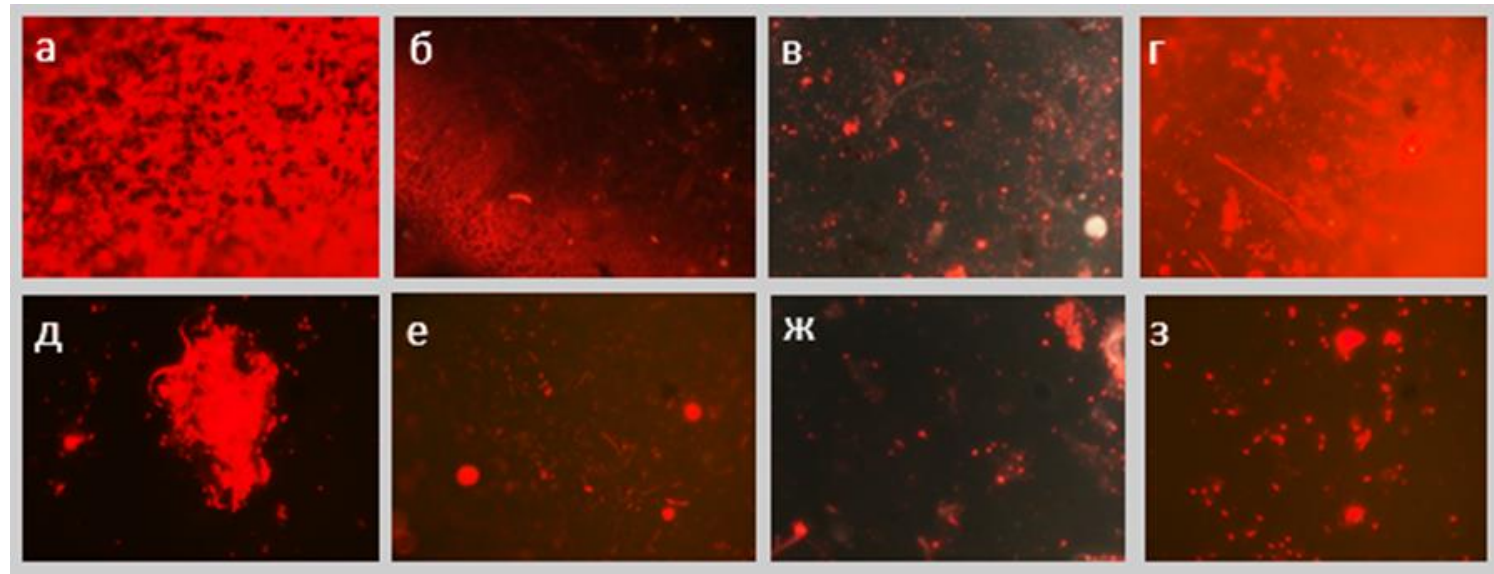

Рис. 3. Морфологическое разнообразие микроорганизмов, окрашенных акридиновым оранжевым, в пробах надшламовой воды: а-з - карты, как на рис. 2 

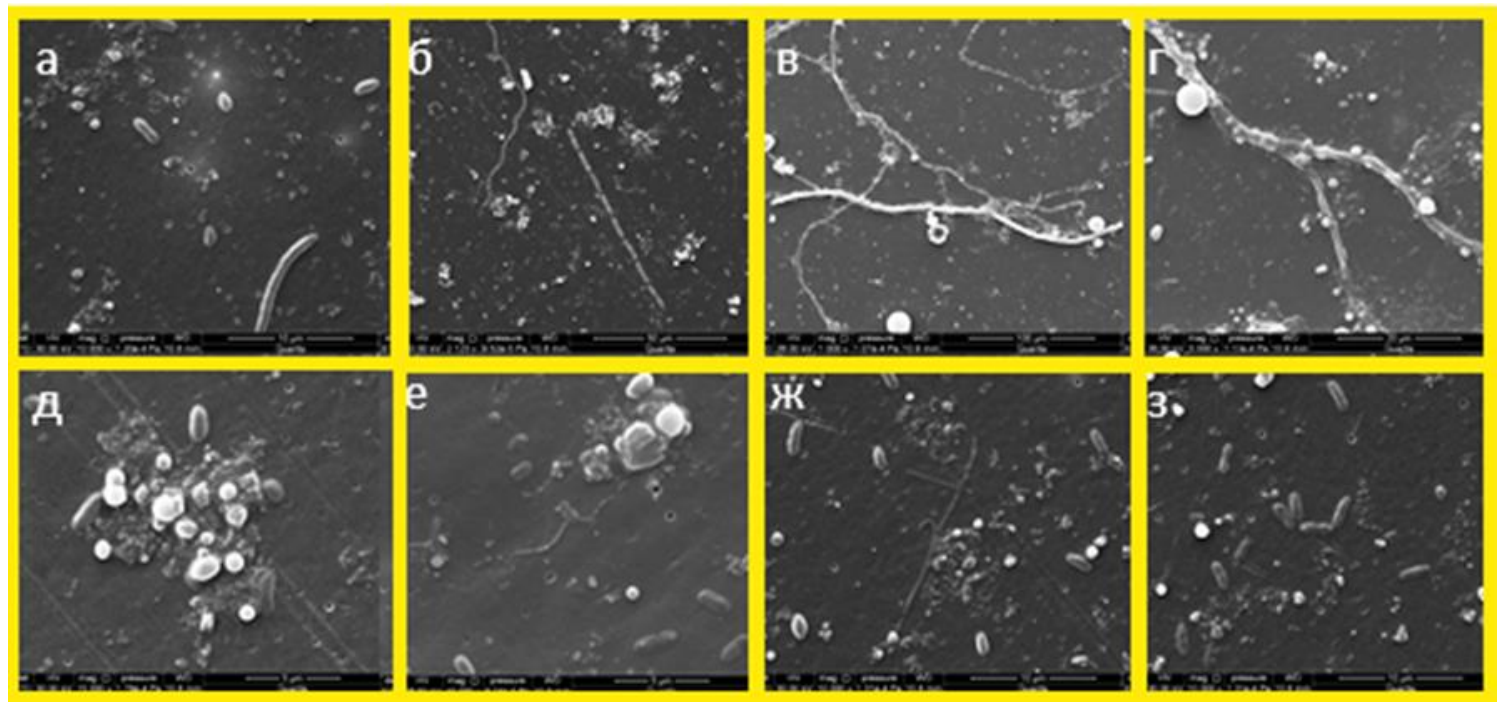

Рис. 4. Разнообразие микробного сообщества в пробах воды из разных карт (сканирующая электронная микроскопия): а-з - карты, как на рис. 2. Масштаб: а, ж, з - 10 мкм; б - 50 мкм; в - 100 мкм; г - 20 мкм; д, е - 5 мкм

Гетеротрофные бактерии. Эти микроорганизмы являются показателями наличия легкодоступного органического вещества. Количество гетеротрофных бактерий в надшламовой воде было высоким и составляло от 24 до 660 тыс. кл./мл (табл. 1). Особенно большое число их обнаружено в воде из карт «Б-4» и «Б-5» (рис. 1, табл. 1). Такое количество гетеротрофных бактерий характерно только для очень загрязненных вод, с возможным содержанием условно-патогенных и патогенных микроорганизмов. В лигнине значительные численности

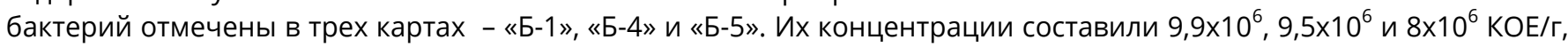
соответственно.

Целлюлозоразрушающие бактерии. В пробах надшламовой воды только в карте Б-6 были обнаружены целлюлозоразрушающие бактерии в концентрации 1,7×104 KOЕ/мл, в остальных картах они либо не были обнаружены, либо были в незначительных количествах. В лигнине эти микроорганизмы были обнаружены в карте «Б-6» и в карте «Б-9». Их концентрации были низкими и составляли $8 \times 10^{2}$ и 10×10² КОЕ/г соответственно. После проведения теста на присутствие этих бактерий в пробах шлам-лигнина было установлено, что бактерии этой группы присутствовали во всех пробах.

Грибы и актиномицеты. Численность грибов в воде всех карт была очень невысокой - наибольшая в картах «Б-5» и «Б-6». (130 и 100 КОЕ/мл, соответственно). Максимальное количество актиномицетов в воде - 50 КОЕ/мл - также в карте «Б-б». В пробах лигнина наибольшие численности грибов зафиксированы в картах «Б-2» и

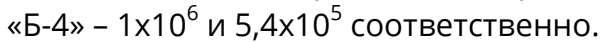

Сульфатредуцирующие бактерии. В ходе отбора проб было отмечено выделение газов со дна некоторых карт. Мы предположили, что это сероводород, являющийся продуктом реакции восстановления сульфатных ионов. В ходе анализа шлам-лигнина на наличие сульфатредуцирующих бактерий было выявлено отсутствие этой группы бактерий в пробах, что указывает на то, что процесс сульфатредукции идет в более глубоких слоях залегания лигнина при анаэробных условиях.

Бактерии группы кишечной палочки и энтерококки. Состав и свойства городских смешанных сточных вод (промышленно-бытовых) определяются соотношением хозяйственно-бытовых и промышленных стоков и спецификой предприятий, формирующих эти стоки. Дополнительные трудности при их обеззараживании возникают в связи с тем, что микробное загрязнение этих вод сочетается с разнообразными органическими и неорганическими веществами, которые сами по себе могут быть как дополнительными бактерицидами и бактериостатиками, так и служить благоприятной средой для размножения микроорганизмов. Согласно методическим указаниям МУ 2.1.5.732-99 (1999), количество общих колиформных бактерий КОЕ/100 мл должно быть не более $10^{5}$. Анализ проводили для карт «Б-3» и «Б-5». В обеих картах выявлено наличие энтерококков. Количество же ОКБ в карте «Б-З» оказалось 5,6×103, а в карте «Б-5» - 2,3×103 КОЕ/100мл, что говорит о соответствии данных сточных вод нормам методических указаний.

\section{Заключение}

Исследования количественных характеристик микроорганизмов, а также их микроскопический анализ показали, что в воде имеет место развитие целого комплекса микроорганизмов (грибы, длинные и короткие формы палочковидных бактерий, кокковые формы бактерий), которые и ведут процесс деградации органического вещества различной природы. Это сообщество представляет собой бактериальное и грибное сообщество, которое развивается с различной интенсивностью в зависимости от экологических условий. Особое место занимают плесневые грибы, актиномицеты, спорообразующие микроорганизмы, которые являются показателями наличия 
Malnik, V.V., Suturin, A.N. (2017 The diversity of microorganisms .... Acta Biologica Sibirica, 2017, 3(3), 32-38

органического вещества, трудно поддающегося любому типу разрушения, будь то химическое окисление или микробиологическая деструкция.

Анализ микробиологических сообществ в картах-накопителях показал, что в картах со шлам-лигнином микробиологическая активность минимальная. В захороненном под слоем золы шлам-лигнине (карты «Б4-Б7») процессы деструкции не наблюдались. В восстановительных условиях идет преобразование сульфатов с выделением сероводорода и метилмеркаптана.

Таким образом, мы исследовали несколько различных групп микроорганизмов в надшламовой воде и лигнине, определили их концентрации, выявили морфологию клеток или наличие и отсутствие мицелия в пробах, а также сделали вывод о сохранении лигнина в его неизменном виде. В качестве возможного решения проблемы утилизации шлам-лигнина предлагаем преобразовать его путем внесения микробиологических препаратов (активных штаммов бактерий-деструкторов лигнина) с последующим преобразованием в нетоксичный почво-грунт, который может быть использован для рекультивации промплощадки.

\section{Благодарности}

Авторы выражают благодарность Ю.А. Дамбинову и Хахураеву О.А. за помощь в отборе проб. Работы выполнена в рамках темы ФАНО № 0345-2016-0010 «Влияние изменяющихся природных и антропогенных факторов на биогеохимические процессы на каменистой литорали Байкала». Микроскопические исследования проведены в ЦКП «Электронная микроскопия», входящем в ОЦКП «Ультрамикроанализ» ЛИН СО РАН.

\section{References}

Argyropoulos, D.S., Menachem, S.B. (1997). Lignin. In: Eriksson K.E.L., Ed. Advances in Biochemical Engineering Biotechnology, 57. Germany, Springer, 127-158.

Brunow, G. (2001). Methods to reveal the structure of lignin. In: Steinbüchel, A., Hofrichter, M., Eds. Biopolymers, 1 Lignin, humic substances and coal. Weinheim, Germany, Wiley-VCH, 89-116.

Galbe, M., Zacchi, G. (2007). Pretreatment of lignocellulosic materials for efficient bioethanol production. Adv. Biochem. Engineer. Biotechnol., 108, 41-65. doi:10.1007/10_2007_070.

Gorbenko, Yu.A. (1961). Microbiologiya, 30(1), 168-172. (In Russian)

Danilatos, G.D. (1986). Environmental scanning electron microscopy in colour. J. Microscopy, 142, $317-325$. doi:10.1002/sca.4950080104.

Endo, S. (1904). Zentralbl. Bakteriol., Abt. I. Orig., 35, 109.

Hobbie, J.E., Daley, R.J., Jasper, S. (1977). Use of Nucleopore filters for counting bacteria by fluorescence microscopy. Appl. Environ. Microbiol., 33, 1225-1228.

Hammel, K.E., Cullen, D. (2008). Role of fungal peroxidases in biological ligninolysis. Curr. Opin. Plant. Biol., 11, 349355. doi: 10.1016/j.pbi.2008.02.003.

Jing, L.I., Hongli, Y., Jinshui, Y. (2009). Bacteria and lignin degradation. Front. Biol. China, 4(1), 29-38. doi: 10.1007/s11515-008-0097-8.

Jones, J.G., Simon, B.M. (1975). An investigation of errors in direct counts of aquatic bacteria by epifluorescence microscopy, with reference to a new method for dyeing membrane filters. J. Appl. Bacteriol., 39, 317-329.

Kersten, P., Cullen, D. (2007). Extracellular oxidative systems of the lignin-degrading Basidiomycete Phanerochaete chrysosporium. Fungal Genet. Biol., 44, 77-87. doi:10.1016/j.fgb.2006.07.007.

Kuznetsov, S.I., Romanenko, V.I. (1963). Microbiologicheskoe izuchenie vnutrennikh vodoemov. Moscow-Leningrad, Izdatelstvo Akademii nauk SSSR. (In Russian)

Lengler, G., Drevs, G., Shlegel', G. (2005). Sovremennaya microbiologiya. Prokarioty: v 2-kh tomakh. M.: Mir. (In Russian) Martínez, A.T. (2002). Molecular biology and structure - function of lignin-degrading heme peroxidases. Enzyme Microb. Technol., 30, 425-444. doi: 10.1016/S0141-0229(01)00521-X.

Martínez, A.T. Speranza, M., Ruiz-Duenas, F.J., Ferreira, P., Camarero, S., Guillen, F. (2005). Biodegradation of lignocellulosics: microbiological, chemical and enzymatic aspects of fungal attack to lignin. Int. Microbiol., 8, $195-204$.

Monties, B., Fukushima, K. (2001). Occurrence, function, and biosynthesis of lignins. In: Steinbüchel, A., Hofrichter, M., Eds. Biopolymers, 1 - Lignin, humic substances, and coal. Weinheim, Germany, WileyVCH, 1-64.

Rodina, A.G. (1965). Metody microbiologicheskogo issledovaniya vodoemov. Moscow, Nauka. (In Russian)

Ruiz Duenas, F.J., Martinez, A.T. (2009). Microbial degradation of lignin: how a bulky recalcitrant polymer is efficiently recycled in nature and how we can take advantage of this. Microbial Biotechnology, 2, 164-177. doi: 10.1111/j.17517915.2008.00078.x.

Sanitarno-epidemiologicheskiy nadzor za obezzarazhivaniem stochnykh vod UF izlucheniem (1999): MU 2.1.5.732-99.M. (In Russian)

Sixta, H. (2006). Handbook of Pulp. Weinheim, Germany, Wiley-VCH.

Suturin, A.N., Goncharov, A.I., Dambinov, Yu.A. (2015). Rekultivatsiya kart-shlamonakopiteley Baikalskogo TsBK. Tsellulosa. Bumaga. Karton, 6, 2-4. 
Taylor, T.N., Osborne, J.M. (1996). The importance of fungi in shaping the paleoecosystem. Rev. Paleobot. Palyn., 90, 249-262.

\section{Citation:}

Malnik, V.V., Suturin, A.N. (2017). The diversity of microorganisms inhabiting the sludge tanks of Baikalsk pulp and paper plant (BPPP). Acta Biologica Sibirica, 3 (3), 32-38.

Submitted: 24.06.2016. Accepted: 14.08.2017

cross ref $\underline{\text { http://dx.doi.org/10.14258/abs.v3i3.3613 }}$

(C) 2017 by the authors. Submitted for possible open access publication under the terms and conditions of the Creative Commons Attribution (CC BY) license (http://creativecommons.org/licenses/by/4.0/). 